variable not conveniently at our command is their phase. Now the Patterson of a crystal can be built up by superimposing elements of a Fourier series, all of which are in phase at the origin or cell corners. The elements of the series are proportional to the measured $\mathrm{X}$-ray intensities. If therefore holes are drilled in the screen $G$ to represent, as cross grating spectra; the intensities of the observed X-ray spectra, the result at $F$ is the Patterson diagram which light has calculated for us from the X-ray results. An example is given in the second article quoted above.

These methods of calculation are as yet in their initial stages, and much remains to be done to perfect them. The success already obtained, in particular with the 'fly's eye' method, is, however, quite promising and they may well prove to be a useful additional weapon in the X-ray analyst's armoury.

1 Nature, 152, 411 (1943).

Nature, 158, 81 (1944)

Nature, 148, 678 (April 22, 1939); 149, 470 (April 25, 1942).

\section{WEST AFRICAN AGRICULTURE}

\section{By SIR GEOFFREY EVANS, C.I.E. Royal Botanic Gardens, Kew}

$\mathrm{I}$

$\mathrm{N}$ the spring of 1938 the Trustees of the Leverhulme Trust invited four members of Parliament to visit West Africa and report upon conditions in the West African Colonies generally. The terms of reference included a study of the standard of life of the native population, the production of food and other materials and in particular certain problems in respect of the development of agriculture, pastoral work and forestry. The investigations considered the problem of the improvement of farming methods and the introduction of new crops; the study of export crops, forestry and animal husbandry and the general problem of soil conditions, including erosion and improvement by better methods, of cultivation. Lastly, the existing systems of land tenure were examined with the view of ascertaining whether modifications would be likely to be advantageous in the fullest development of the land. These objects were distinct from the more political aspects of the work of the Commission, and for the purpose of the inquiry certain technical experts were attached. The Technical Reports of the Commission have now been published; that on crop production and soil fertility is a valuable and informative document*. The Commissioners in their foreword to the Report lay down a principle-with which all who have acquaintance with these territories will agree-that any. future economic development must be based on the fundamental importance of farming as the major interest of the African people. In view of this the Leverhulme Trust was fortunate in securing the services of such eminent men of science as Mr. H. C. Sampson, with his unrivalled knowledge of agricultural problems in India and East Africa; and Dr. E. M. Crowther, head of the Chemistry Department of Rothamisted, who is an acknowledged authority on tropical soil problems.

The outbreak of hostilities delayed the publication

* The West Africa Commission, 1938-39. Technical Reports. 1. Crop Production and Soil Fertility. By H. C. Sampson and Dr. E. M. Crowther. (London: Leverhulme Trust.) of this Report, and in the meantime the impact of war during the last five years has had the effect of chang. ing conditions in West Africa as in other parts of the world. Nevertheless, the Report gives a faithful and very detailed account of agricultural conditions in the West African Colonies, and the facts related, together with the general conclusions reached, are as true to-day as they were before the War, for certain of the fundamental problems involved cannot be settled in a few years, but will only be resolved as the result of a well-planned and carefully thought out policy applied over a number of years.

The need for organizing research and survey on a much larger scale is stressed with the objective of working out an ecological interpretation of the country and its mode of life. That such surveys are needed is generally conceded, but progress in this direction has been hampered by lack of trained staff. The most striking piece of work hitherto has been achieved in the extreme north of the Northern Territories of the Gold Coast. Here a detailed ecological survey of the thickly populated strip of country comprising the granitic soils of the Dagombo peoples has been followed by the application of a definite system of improved agricultural methods. Elsewhere this principle has been adopted in a more piecemeal manner, but it may be said that in all cases where definite progress has been made, it has always followed the preliminary study of native methods of cultivation and has usually resulted in the grafting of the improved methods on to the native systems rather than the introduction of completely novel methods.

The section on geology and soils forms a valuable addition to our knowledge, and it is worth the study of all officers, administrative as well as agricultural, for the improvement, and, in the final instance, the saving of the soil, is the basis of all agricultural prosperity. The interesting suggestion is put forward that many of the traditional agricultural practices are to be explained in terms of the mineral nutrients necessary for plant life. Generally speaking, it may be said that West African soils are not particularly fertile, and indeed in large areas they are definitely poor. Organic matter decomposes much more rapidly in the tropics than it does in temperate climates, and many of the soils in the dry tropies are short of humus. Most of the surface soils in the wet zone are very deficient in bases and notably lime, phosphates, and potash ; an exception being the rich volcanic country around the Cameroon Mountain.

The general shortage of lime is evident in many ways. Thus the native cattle and wild animals are smaller in the wet areas, where the lime and other minerals are readily leached out of the soil by the heavy rain, than in the dryer zones to the north. In the forest areas where cattle can with difficulty live owing to the attentions of the tsetse fly, the application of farmyard manure is not practicable, and experiments are now being conducted by the Agricultural Departments in Nigeria, in particular, to try to replenish the surface soils by means of the residues of certain deep-rooted shrubs which it is believed will draw these mineral nutrients from the subsoil. There are large areas in the country east of the Niger where the soil is so poor that it is impossible to establish a leguminous cover crop, and it is presumed that this is due to the lack of essential minerals. The present custom of cutting and burning the bush, growing a couple of crops and then allowing the land to recover by reverting to bush for a long series of 
years, although destructive to timbër supplies, was fairly effective so long as there was a sparse population. But in the Ibo country east of the Niger, the population is increasing rapidly and already in some districts it is 1,200 to the square mile. Here the resting period has perforce had to be reduced to two or even one year, so that this land has no time to recover and is rapidly deteriorating. There is no doubt that the evolution of a permanent system of husbandry in the wet forest area is one of the most pressing problems and also one of the most difficult to solve. It is a matter requiring careful and continuous investigation over a series of years. It is believed that these deeprooted species, such as the rosaceous shrub Acioa barteri, bring up nutrients from the subsoil, but there seems to be no definite knowledge with regard to the extent to which this occurs, and detailed information would be advantageous. A central research station to deal with these problems of cultivation in the Forest Belt is badly needed, since a solution is probably the most urgent of all tropical agricultural problems at present.

In the drier parts of the country where it is possible to keep livestock, considerable progress has been made in establishing systems of mixed farming, whereby farmyard manure becomes available for the replenishment of the soil.

Somewhat remarkable results have been obtained by the application of dressings of one or two tons an acre. Such light applications would be considered homoopathic in Great Britain, and an interesting theory is put forward that the increase in yield may be due, in the main, to the minerals and not so much to the humic content of the manure. Further trials with mineral fertilizers are advocated. Phosphates in particular appear to be short, and it is pointed out that whereas rock phosphates may give good results in the acid soils of the Forest Belt, the more soluble fertilizers such as superphosphate may give better results in the neutral soils of the north. The argument that the peasant is so poor and so conservative that he will never readily take to artificial fertilizers is really unsound. In India the ryot, who was always considered one of the most conservative of beings, now uses large quantities, but he had to be converted to the value of the practice by prolonged and visual demonstrations. It must also be remembered that large numbers of African peasants have joined the Armed Forces during the last four years and have gained a measure of education and a widening of outlook which will undoubtedly have a big effect on village life when they return after demobilization. All these men will have travelled a good deal and will have learnt a lot from their contact with other peoples and other countries. Most of them have learnt to think for themselves, and will be quicker to take up any new method which promises to be advantageous.

As has already been mentioned, the African:soils are deficient in certain important plant foods. The discovery of good deposits of agricultural lime or a reef of good phosphatic rock would be of untold benefit. There are phosphatic rocks in the Yoruba country, but there is no factory for making superphosphates. As it is at present, the country is losing most of its minerals through the export crops such as oil seeds and cacao. The north is also losing vast quantities in the shape of its eattle and animal products. If means could be found to slaughter the cattle in the north instead of sending them down to the coast on the hoof, the bones, horns and other residues could be retained and worked up into super- phosphates, dried blood and other fertilizers, and the minerals would find their way back to the land where they came from. As it is at present, the drain from the land each year, in the shape of ground-nuts exported to the coast, is very considerable.

On the subject of erosion the authors very rightly stress the need for urgent action. Soil erosion is evident everywhere to a greater or less degree, and is particularly severe in the Protectorate of Sierra Leone, where the burning of steep slopes for the cultivation of hill rice is causing a rapid loss of soil and the impoverishment of whole areas. In the Ibo country of south-east Nigeria erosion in its most spectacular form is seen, particularly in the Awka division. Here the soils are a light sand, and enormous chasms several hundred feet deep and miles long have been formed. These are extending rapidly and encroaching on the agricultural land, which is already overburdened with a heavy population. Many of these areas are already gone beyond hope of reclaiming, and the best that can be done is to proclaim them forest reserves and get them covered with some sort of tree growth as quickly as possible. The real problem is to prevent further erosion by tackling incipient gulleying at the source and preventing sheet erosion by contouring, strip cultivation and bunding in the fields that are in cultivation. The problem is an administrative one and needs a united drive on the part of the political officers and the local authorities with the technical advice of agricultural and forestry officers. The whole problem involves careful planning, and decisions have to be made with regard to the allocation of certain areas as forest reserves in order to protect the water sheds and to afford shelter belts. The latter are particularly important as a protection against wind erosion in the dryer areas of the north where top soil may be lost by 'blowing', but it is also important in the regions nearer the coast because indiscriminate felling of the forests allows the 'harmattan' - that intensely dry north wind from the Sahara-access to the cacao plantations which require a humid atmosphere for their proper development. Incidentally the belief, current in many quarters, that the fine sand blown by the harmattan is altogether deleterious is not quite correct. It is pointed out that it is not a sand, but is composed of alkaline clay far richer in plant foods than the soils on which it falls, and although only small amounts are deposited each year they are likely to do more good than harm.

It is impossible to refer in detail to the section on crop plants, which are described in some detail, but some reference must be made to cotton and cacao. The former crop is chiefly grown in the Zaria province in Northern Nigeria, and eomplaints have been made from time to time that the type of American Upland cotton now grown is weak in staple. It is suggested that other species of cotton such as G. punctatum or some of the old native cottons might be developed. Shortage of staff and war conditions have prevented action being taken on these lines. Meanwhile, it is worth noting that the Upland cotton, which is an annual crop, seems to produce good strong cotton up to the advent of the harmattan winds in January. When these winds set in the cotton plants suddenly dry up and wilt, and any cotton picked afterwards tends to ripen prematurely and to be very weak in staple. It would seem desirable, therefore, to gin and bale this later picking separately from the main crop, which is picked before the coming of the harmattan. 
With regard to cacao, much has happened since this Report was written. It is a remarkable fact that cacao plantations all over the world are now' suffering much damage from diseases and pests. The effect seems to become cumulative as the crop reaches about thirty years. During the last five years officers working in the Research Station at Tafo, which was opened in 1937, have discovered that much of the damage that was formerly ascribed to die-back or physiological trouble is in reality caused by a virus or a virus complex, one symptom of which is the 'swollen shoot'. These viruses, together with the attack of capsid bugs, is menacing the whole future of the cactu crop, which is the prop and stay of the Gold Coast. The cacao has shown signs of trouble for years past; but it is only as recently as 1937 that researeh was contemplated. Now that the danger is apparent, the step recently taken to convert the Tafo Station into a Central Cacao Research Station to serve the whole of West Africa is a great step forward. The Station can now hope to be adequately staffed and equipped, and continuity in the research work will be assured, which was not always the case under the former conditions.

The sections dealing with the types of West African agriculture give a most interesting and accurate account of the methods and will repay careful study.

As regards plantation agriculture, it is pointed out that the present systems of land tenure and Government policy tend to hinder European plantations in our West African Colonies, though this is not the ease in adjoining French territories or in the Belgian. Congo. So far as the production of crops for export is concerned the plantation system has undoubtedly many advantages over production by large numbers of small individual farmers. It must be remembered that most of these tropical export crops have to be processed in some form or another before they can be marketed. The plantation with its central factory and assured supply of raw material can do this more efficiently and turn out a better product than the small individual. Arrangements can also be made to plant only the best varieties and to effect improvements in planting methods. It is also in a better position to meet the demands of the markets as regards quality, grade and so on, and has a big advantage in the arrangements concerning transport and sale. It was for these reasons that the plantation products of the Far East were rapidly ousting similar products from the West Coast in the period before the War. It would seem necessary to realize that some sort of central organization will be essential in the future and methods need to be worked out whereby the plantations can be organized on a eo-operative or collective basis. By this means crops would be raised by individuals retaining many of their old rights and growing their own food crops, but collected round a central factory which would do the processing and arrange for the marketing and transport. A suitable site for such an experiment would be in the British Cameroons. Here agriculture is already based on the plantation system and these plantations, which were formerly enemy property, are being managed temporarily by Government. The soils are extremely fertile and other conditions favourable, and the experiment would be well worth making.

The Report is in every way an informative one and is illustrated by a series of excellent photographs which give a good idea of the lives and occupations of the various races that live in the British West African Colonies.

\section{EDUCATION IN PREVENTIVE MEDICINE}

\author{
By SiR ARTHUR MACNALTY, K.C.B.
}

TN exploring a fresh field of knowledge in any sub1 ject, the pioneers have all the fun of the game. They devise their own methods and rules for investigation and try them out experimentally. It is necessary at length, when results have been achieved, to hand on the torch to others, and eventually an educational system, with professorial chairs, lecturers, text-books, demonstrations and the whole gamut of didactic instruction makes its appearance.

The preventability of disease had its ordered beginnings in the eighteenth and early part of the nineteenth centuries, and British practitioners of medicine took the lead of the world in this study. Richard Mead, in 1720, published his "Short Discourse concerning Pestilential Contagion and the Methods to be Used to Prevent it". John Pringle began hygienic reform for the British Army, and Dr. James Lind prevented scurvy and typhus. Other pioneers in preventive medicine were George Baker, Gilbert Blane, Edward Jenner and Turner Thackrah.

These men were all clinicians; they saw the con. sequences of disease, were not content with alleviating or euring maladies, but sought out their causes. In many cases they discovered that their patients' illhealth was due to bad environmental eonditionspoverty, overcrowded dwellings, lack of fresh air and ventilation, filth, dirt and defective sanitation. Clinical medicine produced preventive medicine and constitutes its backbone. by a natural process of events, this new knowledge led to sanitary legislation, to a public health service and to systematic education in preventive medicine.

In an interesting inaugural lecture at the London School of Hygiene and Tropical Medicine, Prof. J. M. Mackintosh has traced the history of this education and foreshadowed its future trends.

It began in the year 1786 with Johann Peter Frank, who held the chair of elinical medicine in the University of Pavia and was appointed director of public health of Austrian Lombardy. In 1789 Andrew Duncan became professor of the Institutes of Medieme in Edinburgh and from 1795 gave weekly lectures on medical jurisprudence, devoting part of the course to the subject of "Medical Police", in which he dealt with both personal and environmental health, including hospitals and contagious diseases. In 1807 a university chair was created in these subjeets with the stipend of $£ 100$ a year. At this time a number of British teachers were leeturing privately on hygiene, and books were written on the subject. John Roberton's treatise on "Medical Police" appeared in 1809, and in 1824 Gordon Smith defined the subject as "the application of medical knowledge to man in his social state" - no bad definition of social medieine. It was not until the year 1898 that the University of Edinburgh again had the distinction of instituting the first whole-time chair of publie health.

The brilliant work of Sir John Simon and his colleagues at the Central Health Authority, and the appreciation of the work of those medical officers of health appointed by Liverpool, London and other progressive authorities, led to the obligatory general appointments of such offieers by each local authority in 1872. By the Medical Act of 1886 (Section 21) 